\title{
Optimisasi Ukuran Utama Kapal Roll On - Roll Off (Ro-Ro) Menggunakan Software Visual Basic dan Maxsurf
}

\author{
Rahardian Ahmad Fauzi, Gita Marina Ahadyanti, dan Hasanudin \\ Departemen Teknik Perkapalan, Fakultas Teknologi Kelautan, Institut Teknologi Sepuluh Nopember (ITS) \\ e-mail : hasanudin@na.its.ac.id
}

\begin{abstract}
Abstrak-Kapal ferry Ro-Ro adalah moda transportasi yang paling banyak digunakan untuk menghubungkan pulau-pulau di Indonesia. Di Indonesia intensitas bencana karena faktor alam relatif tinggi, sehingga banyak kapal ferry Ro-Ro yang mengalami kecelakaan. Selain karena faktor alam kecelakaan kapal ini juga terjadi akibat karakteristik kapal yang kurang sesuai untuk kondisi alam daerah tersebut. Oleh sebab itu, penggunaan metode optimasi sangat tepat untuk menyelesaikan persoalan ini dengan menghasilkan desain kapal baru yang memiliki karakteristik teknis yang lebih sesuai dengan kondisi perairan di rute pelayaran tersebut. Salah satu rute pelayaran yang sering terjadi kecelakaan adalah rute Pelabuhan Bajoe - Pelabuhan Kolaka. Metode optimasi yang digunakan adalah global optimization dengan menggunakan artificial neural network. Optimasi dilakukan dengan menggunakan software visual basic dan maxsurf dengan studi kasus kapal ferry (Ro-Ro) rute Pelabuhan Bajoe - Pelabuhan Kolaka. Dari hasil optimisasi yang dilakukan dengan 1-10 nilai train, didapatkan ukuran utama yang memenuhi batasan optimisasi dan ukuran utama yang paling optimum adalah Lpp $=$ $56,258 \mathrm{~m}, \mathrm{~B}=\mathbf{1 2 , 8 8} \mathrm{m} \mathrm{H}=4,046 \mathrm{~m}$ dan $\mathrm{T}=2,592 \mathrm{~m}$ dan fungsi objektif yaitu meminimumkan biaya pembangunan kapal dengan nilai $\$$ 8.523.954,64. Perbandingan estimasi biaya pembangunan kapal existing dan estimasi biaya pembangunan hasil optimasi adalah $10,58 \%$ dengan selisih biaya pembangunan sebesar $\$$ 1.008.473,03. Sehingga hasil optimasi tersebut menghasilkan fungsi objektif yang lebih optimum.
\end{abstract}

Kata Kunci-Ferry Ro-Ro, Global Optimization, Visual Basic For Application, Maxsurf.

\section{PENDAHULUAN}

$\mathrm{K}$ EMAJUAN teknologi informasi mempengaruhi perkembangan perancangan desain kapal. Hingga sekarang, proses desain kapal ini dilakukan secara berulang ulang untuk mendapatkan ukuran utama yang diinginkan. Proses ini disebut dengan spiral design. Akan tetapi proses ini memerlukan waktu yang lebih lama untuk menentukan besarnya ukuran utama yang diinginkan. Oleh karena itu, banyak yang sudah mengembangkan metode untuk mempercepat proses desain kapal. Salah satunya adalah metode optimisasi.

Optimisasi ialah suatu proses untuk mencapai atau mendapatkan suatu fungsi maksimal atau minimal dengan hasil yang optimum [1]. Untuk mendapatkan nilai yang optimum dilakukan perubahan pada komponen variabel yang dibatasi oleh batasan-batasan dan objective function sebagai penentu tingkat optimum. Metode optimisasi yang digunakan dalam tugas akhir adalah non linier constrains optimization menggunakan artificial neural network, objective function yang digunakan adalah meminimalkan biaya pembangunan kapal dan constraints yang digunakan adalah karakteristik teknis dan keselamatan kapal. Dalam pembuatan progam komputer ini menggunakan software visual basic dan maxsurf dengan studi kasus kapal Ro-Ro rute pelayaran Pelabuhan Bajoe - Pelabuhan Kolaka. Kapal Ro-Ro adalah kapal ferry yang dirancang memiliki dua pintu ramp doors. Rute ini dipilih karena memiliki gelombang yang relatif tinggi dan terjadi beberapa kecelakaan kapal [2]. Oleh sebab itu, dibutuhkan suatu progam komputer dalam pengembangan optimisasi yang menghasilkan desain kapal baru untuk mengatasi permasalahan tersebut.

\section{TINJAUAN PUSTAKA}

\section{A. Perkembangan Kapal Ferry Ro-Ro}

Pada tahun 1950 banyak terjadi inovasi terhadap penangan kargo yang terfokus dalam pengembangan desain kapal. Salah satu nya yang sukses dikembangkan adalah kapal Ro-Ro. Bagaimanapun juga, kapal roll on/roll off atau kapal dengan pondasi kayu yang dapat mengambang dibangun untuk menyeberangi sungai dan membawa orang dan kendaraan beroda. Kapal ini ditarik menggunakan tali, yang membentang di seberang sungai, terkadang penumpang diminta untuk membantu menarik kapal tersebut. Platform ini akhirnya dinamai dengan ferry [3].

Kapal ferry merupakan salah satu jenis kapal yang berlayar pada jarak dekat atau kapal yang berlayar dari pulau satu ke pulau yang lain, sehingga dikenal juga sebagai kapal penyeberangan. Kapal ferry yang dirancang dengan memiliki dua pintu ramp doors yaitu pintu depan dan pintu belakang adalah kapal ferry jenis Ro-Ro atau singkatan dari roll-on / rolloff [4]. Kapal Ro-Ro berbeda dari kapal lo-lo(lift on-lift off) yang menggunakan crane untuk memuat kargo [5].

\section{B. Desain Kapal}

Proses desain merupakan proses yang dilakukan secara berulang ulang hingga menghasilkan suatu desain yang sesuai dengan apa yang diinginkan. Dalam design process pembangunan kapal baru terdapat beberapa tahapan desain, [6] yaitu antara lain: concept design, preliminary design, contract design, dan detail design.

\section{Teori Optimisasi}

Spiral Design Process mempunyai kelemahan yaitu prosesnya selalu diulang-ulang secara manual beberapa putaran untuk memenuhi semua constraints sehingga memerlukan waktu yang lama atau bahkan hasilnya tidak optimal. Metode optimasi sangat tepat untuk menyelesaikan persoalan desain 
kapal yang kompleks. Optimisasi adalah suatu tindakan untuk mendapatkan hasil terbaik dalam situasi tertentu [1].

Dengan memanfaatkan optimisasi dalam proses desain maka diharapakan dapat mengurangi ulangan perancanaan seperti desain spiral tidak diperlukan sehingga proses desain kapal lebih terstruktur, keuntungan lainnya yaitu tenaga mesin, kapasitas ruangan dan stabilitas harga dapat ditentukan sejak awal. Pada metode optimisasi dilakukan iterasi satu tahap saja secara otomatis yaitu preliminary design sehingga menghasilkan solusi yang optimal dan waktu yang cepat [7].

Terdapat beberapa faktor yang terlibat dalam proses optimisasi antara lain: variabel, constraint, constant, parameter, dan objective function. Variabel adalah nilai yang berubah dalam suatu sistem optimisasi. Constraint adalah harga batas yang telah ditentukan desainer dan beberapa regulasi. Constant adalah harga yang tidak berubah nilainya selama proses optimasi. Parameter adalah besaran yang telah diberikan dalam pemodelan optimisasi dan tidak berubah selama satu proses optimisasi. Dan objective function adalah nilai yang ingin diminimumkan atau dimaksimalkan dalam optimisasi [8] [9]. Seperti pada Gambar 1.

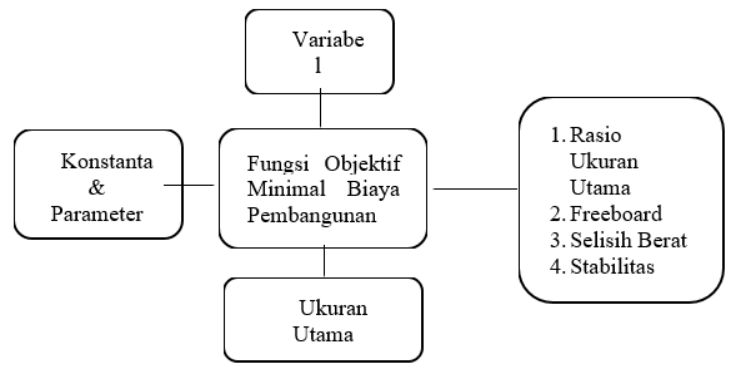

Gambar 1. Diagram optimasi.

Dalam kurun waktu terakhir beberapa metode optimasi telah dikembangkan untuk menyelesaikan beberapa masalah optimasi. Salah satunya adalah metode artificial neural network optimization yang telah digunakan secara luas pada berbagai macam aplikasi engineering [10] [11].

\section{Hubungan Visual Basic for Application dan Maxsurf}

VBA atau biasa disebut Visual Basic for Application adalah sebuah bahasa pemrograman yang yang digunakan untuk mengotomatisasi operasi di aplikasi Microsoft Office seperti Excel, Acces, Word, Power Point dan Outlook. VBA juga dapat dihubungkan dengan aplikasi lain seperti maxsurf, autocad, dan program lainnya dengan menggunakan fitur automation [12]. Automation dalam aplikasi ini memberi pengguna akses ke berbagai objek yang dapat digunakan untuk mengendalikan aplikasi dan datanya [13].

\section{METODOLOGI PENELITIAN}

\section{A. Bagan Alir}

Dalam melakukan penelitian untuk mendapatkan hasil kapal ferry Ro-Ro yang optimum maka dibuatlah bagan alir yang ditunjukkan pada Gambar 2.

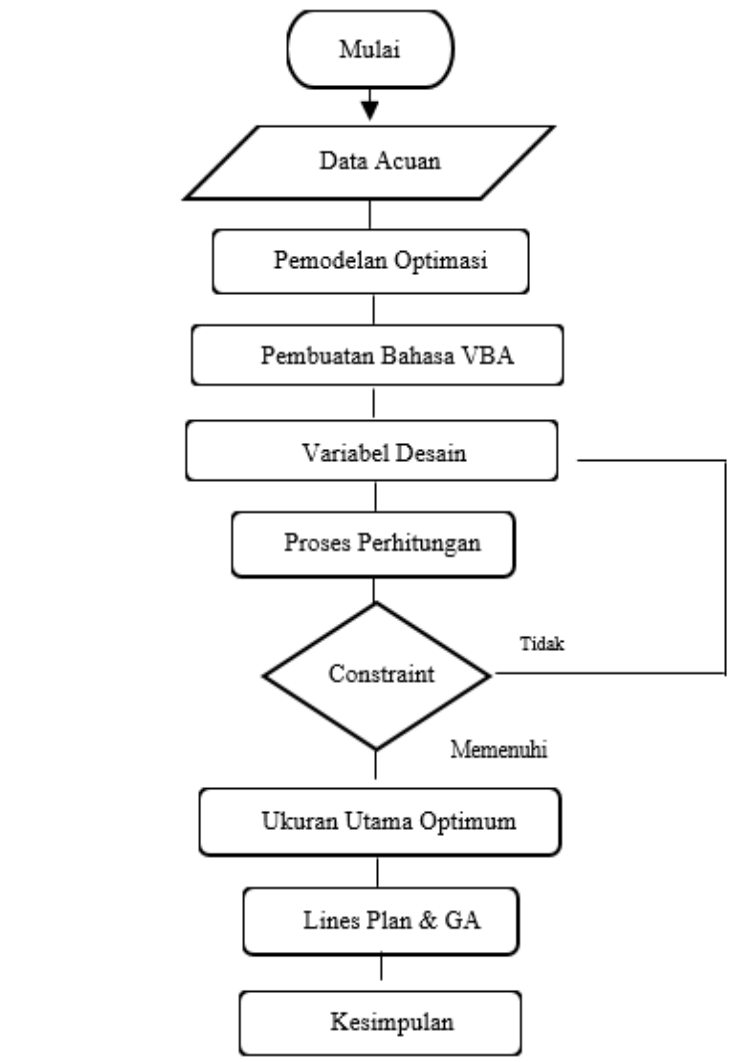

Gambar 2. Diagram alir pengerjaan studi.

\section{B. Pengumpulan Literatur dan Data}

Dilakukan studi pustaka dengan mengambil beberapa sumber pustaka yang relevan untuk mengumpulkan literatur maupun informasi yang diperlukan dalam penelitian, berupa buku, jurnal, laporan, maupun data-data dari situs internet.

\section{Pembuatan Progam dan Link dengan Maxsurf}

Pembuatan logaritma progam dibuat dengan menggunakan Visual Basic Application (VBA) yang terdapat didalam Microsoft Excel serta dihubungkan dengan Software Maxsurf. Cara kerja dari progam ini adalah menarik-narik control point hull kapal yang terdapat di Maxsurf dengan bantuan progam dari Visual Basic for Application (VBA).

\section{Pemodelan Optimisasi}

Pembuatan pemodelan optimasi yang meliputi: variable, parameter, constanta, constrains dan objective function. Variabel optimasi adalah menetukan ukuran utama kapal dengan fungsi objektifnya adalah meminimumkan biaya pembangunan kapal. Parameter dan constraints dari optimisasi didapatkan dari owner requirements yang telah dianalisis sebelumnya, regulasi dan peraturan statutory. Seperti flowchart optimasi berikut ini

\section{E. Analisis Teknis dan Optimasi}

Dari kombinasi variabel atau ukuran utama yang didapatkan dari program selanjutnya adalah melakukan penyaringan atau filter untuk mengetahui kombinasi ukuran utama yang memenuhi batasan. Jika hasilnya tidak memenuhi, maka kombinasi ukuran utama tersebut akan dieliminasi. Setelah hasil penyaringan kombinasi ukuran utama dilakukan, maka 
kombinasi ukuran utama yang baru dipilih berdasarkan nilai fungsi objektif yang terkecil.

\section{F. Desain dan Perancangan}

Dalam tahap ini dilakukan desain dan perancangan dari kapal yang meliputi rencana garis, yaitu desain bentuk badan kapal meliputi body plan, sheer plan dan half-breadth plan, serta sistem propulsi kapal Ferry Ro-RO. Setelah itu dilakukan desain perencanaan umum (general arrangement), rencana keselamatan kapal dan desain 3D.

\section{ANALISIS DAN PEMBAHASAN}

\section{A. Owner Requirements}

Kapal yang dijadikan sebagai referensi untuk menentukan owner requirement adalah kapal KMP Rafelia 2. Penentuan payload didasarkan pada laporan KNKT 2016 bahwa sesuai setifikat keselamatan kapal jumlah maksimal penumpang adalah sebesar 354 orang. Dengan muatan kendaraan berjumlah 10 unit mobil dengan $\mathrm{L} \leq 5 \mathrm{~m}, 10$ unit truck dengan $7 \mathrm{~m} \leq \mathrm{L} \leq$ $10 \mathrm{~m}$, dan sepeda motor dengan jumlah 20 unit. Setelah dilakukan perhitungan didapatkan total berat payload sebesar 178,55 ton.

\section{B. Analisa Hasil Optimasi}

Berikut ini adalah analisa hasil optimasi untuk menghasilkan ukuran utama yang optimum dengan nilai train yang dianalisa adalah $1-10$, dan jumlah variasi ukuran utama adalah $n^{4}$. Sehingga nilai variasi ukuran utama berjumlah $1-10000$.

\section{Kombinasi 1 Variabel}

Dilakukan menggunakan nilai train 1 didapatkan hasil variasi ukuran utama $1^{4}$ sejumlah 1 . Nilai yang tidak memenuhi batasan adalah koreksi displasemen. Pada kombinasi ini nilai variasi ukuran utama tidak memenuhi batasan.

\section{Kombinasi 2 Variabel}

Dilakukan menggunakan nilai train 2 didapatkan hasil variasi ukuran utama $2^{4}$ sejumlah 16. Adapun nilai yang tidak memenuhi batasan antara lain $\mathrm{B} / \mathrm{T}=12, \mathrm{H} / \mathrm{T}=4$, koreksi displasemen $=12$, area $0^{\circ}-30^{\circ}=1$, area $0^{\circ}-40^{\circ}=5$, area $30^{\circ}-40^{\circ}=$ 11 , GZ pada $30^{\circ}=7$ dan GZ maksimal $=12$. Seperti pada Gambar 3 berikut ini. Pada kombinasi ini semua nilai variasi ukuran utama tidak memenuhi batasan.

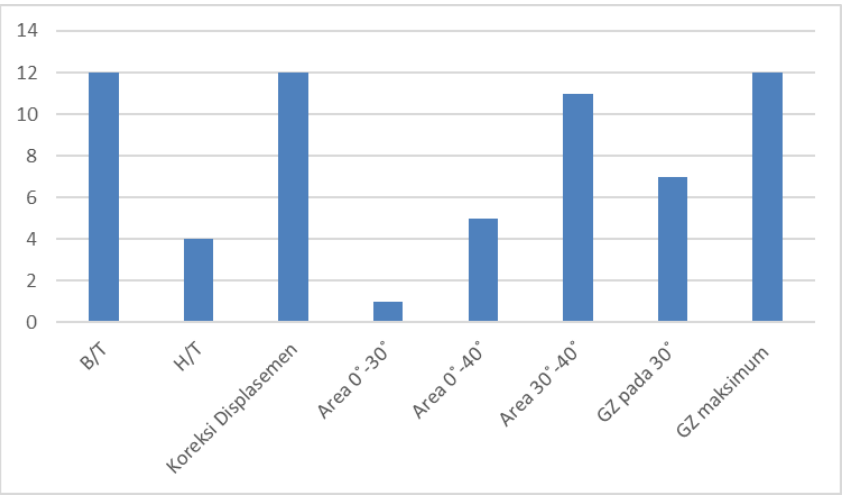

Gambar 3. Grafik jumlah nilai yang tidak memenuhi batasan pada kombinasi 2 variabel.

\section{Kombinasi 3 Variabel}

Dilakukan menggunakan nilai train 3 didapatkan hasil variasi ukuran utama $3^{4}$ sejumlah 81 . Adapun nilai yang tidak memenuhi batasan antara lain $\mathrm{B} / \mathrm{T}=54, \mathrm{H} / \mathrm{T}=27$, koreksi displasemen $=66$, area $0^{\circ}-30^{\circ}=6$, area $0^{\circ}-40^{\circ}=38$, area $30^{\circ}$ $40^{\circ}=53, \mathrm{GZ}$ pada $30^{\circ}=44$ dan $\mathrm{GZ}$ maksimal $=63$. Seperti pada Gambar 4 berikut ini. Pada kombinasi ini semua nilai variasi ukuran utama tidak memenuhi batasan.

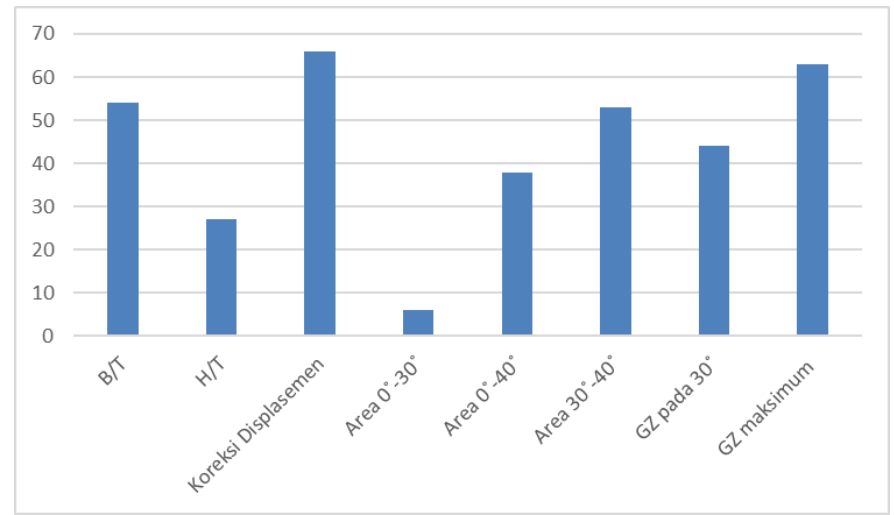

Gambar 4. Grafik jumlah nilai yang tidak memenuhi batasan pada kombinasi 3 variabel.

\section{Kombinasi 4 Variabel}

Dilakukan menggunakan nilai train 4 didapatkan hasil variasi ukuran utama $4^{4}$ sejumlah 256 . Adapun nilai yang tidak memenuhi batasan antara lain $\mathrm{B} / \mathrm{T}=160, \mathrm{H} / \mathrm{T}=96$, koreksi displasemen $=208$, area $0^{\circ}-30^{\circ}=9$, area $0^{\circ}-40^{\circ}=110$, area $30^{\circ}$ $40^{\circ}=175, \mathrm{GZ}$ pada $30^{\circ}=127$ dan GZ maksimal $=200$. Pada kombinasi ini nilai variasi ukuran utama yang memenuhi berjumlah 4 dan yang tidak memenuhi berjumlah 252. Seperti pada Gambar 5 berikut ini. Dari hasil ukuran utama yang didapatkan fungsi objektif terkecil adalah train ke 14 dengan nilai $\$ 8.934 .388,72$ dan ukuran utama $\mathrm{Lpp}=58,093 \mathrm{~m}, \mathrm{~B}=$ $13,3 \mathrm{~m}, \mathrm{H}=4,279 \mathrm{~m}$, dan $\mathrm{T}=2,75 \mathrm{~m}$.

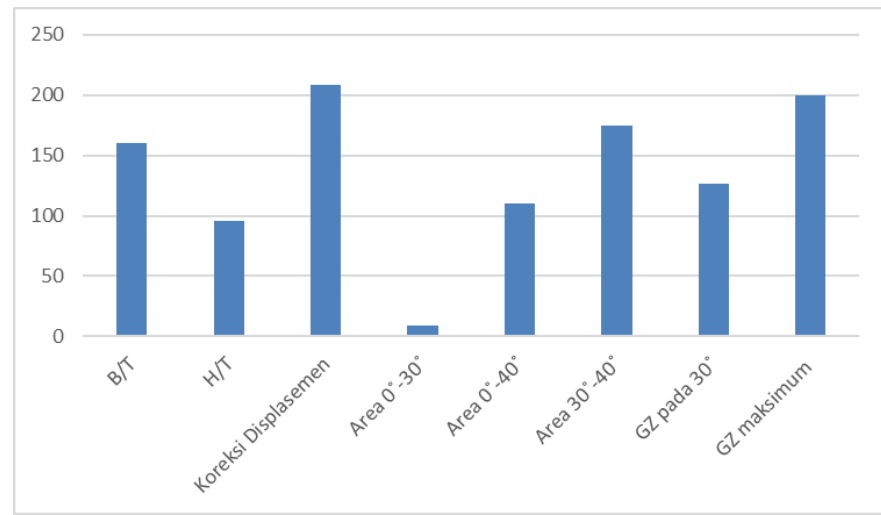

Gambar 5. Grafik jumlah nilai yang tidak memenuhi batasan pada kombinasi 4 variabel.

\section{Kombinasi 5 Variabel}

Dilakukan menggunakan nilai train 5 didapatkan hasil variasi ukuran utama $5^{4}$ sejumlah 625 . Adapun nilai yang tidak memenuhi batasan antara lain $\mathrm{B} / \mathrm{T}=375, \mathrm{H} / \mathrm{T}=250$, koreksi displasemen $=498$, area $0^{\circ}-30^{\circ}=23$, area $0^{\circ}-40^{\circ}=243$, area $30^{\circ}$ $40^{\circ}=394, \mathrm{GZ}$ pada $30^{\circ}=305, \mathrm{GZ}$ maksimal $=505$ dan periode oleng $=2$. Seperti pada Gambar 6 berikut ini. Pada kombinasi ini nilai variasi ukuran utama yang memenuhi berjumlah 10 dan yang tidak memenuhi berjumlah 615. Dari hasil ukuran utama yang didapatkan fungsi objektif terkecil adalah train ke 17 dengan nilai $\$ 8.785 .324,19$ dan ukuran utama $L p p=57,481 \mathrm{~m}$, $\mathrm{B}=13,16 \mathrm{~m}, \mathrm{H} 4,123 \mathrm{~m}$, dan $\mathrm{T}=2,646 \mathrm{~m}$. 


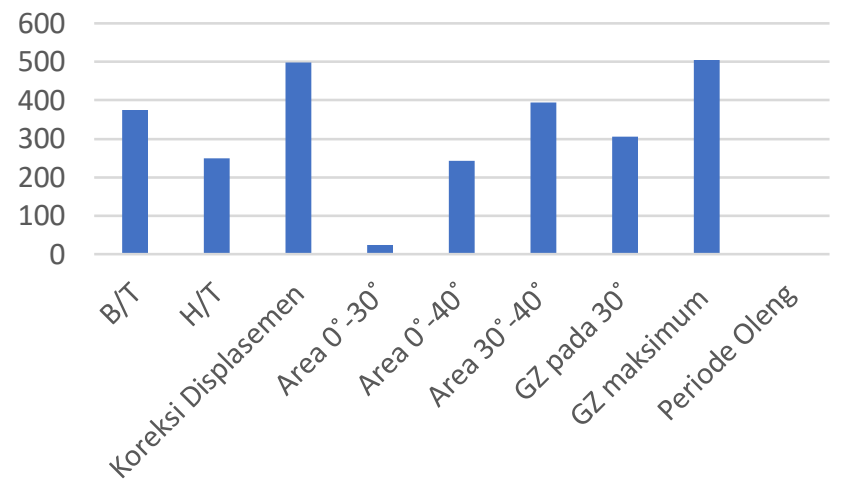

Gambar 6. Grafik jumlah nilai yang tidak memenuhi batasan pada kombinasi 5 variabel.

\section{Kombinasi 6 Variabel}

Dilakukan menggunakan nilai train 6 didapatkan hasil variasi ukuran utama $6^{4}$ sejumlah 1296. Adapun nilai yang tidak memenuhi batasan antara lain $\mathrm{B} / \mathrm{T}=936, \mathrm{H} / \mathrm{T}=540$, koreksi displasemen $=1015$, area $0^{\circ}-30^{\circ}=42$, area $0^{\circ}-40^{\circ}=482$, area $30^{\circ}-40^{\circ}=791, \mathrm{GZ}$ pada $30^{\circ}=599, \mathrm{GZ}$ maksimal $=1053$ dan periode oleng $=6$. Seperti pada Gambar 7 berikut ini. Pada kombinasi ini nilai variasi ukuran utama yang memenuhi berjumlah 6 dan yang tidak memenuhi berjumlah 1290. Dari hasil ukuran utama yang didapatkan fungsi objektif terkecil adalah train ke 33 dengan nilai $\$ 8.722 .639,95$ dan ukuran utama $\mathrm{Lpp}=57,073 \mathrm{~m}, \mathrm{~B}=13,067 \mathrm{~m}, \mathrm{H}=4,279 \mathrm{~m}$, dan $\mathrm{T}=$ $2,7 \mathrm{~m}$.

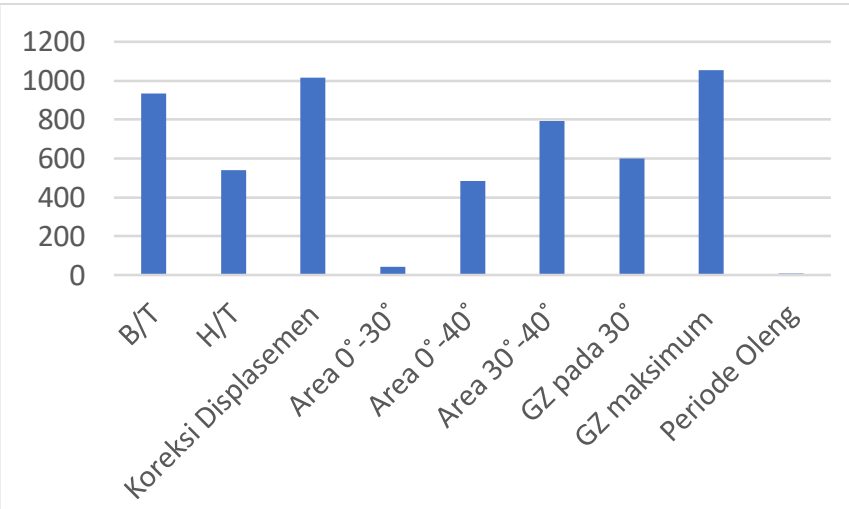

Gambar 7. Grafik jumlah nilai yang tidak memenuhi batasan pada kombinasi 6 variabel.

\section{Kombinasi 7 Variabel}

Dilakukan menggunakan nilai train 7 didapatkan hasil variasi ukuran utama $7^{4}$ sejumlah 2401. Adapun nilai yang tidak memenuhi batasan antara lain $\mathrm{B} / \mathrm{T}=1666, \mathrm{H} / \mathrm{T}=1029$, koreksi displasemen $=1859$, area $0^{\circ}-30^{\circ}=81$, area $0^{\circ}-40^{\circ}=838$, area $30^{\circ}-40^{\circ}=1497, \mathrm{GZ}$ pada $30^{\circ}=1081, \mathrm{GZ}$ maksimal $=1966$ dan periode oleng $=12$. Seperti pada Gambar 8 berikut ini. Pada kombinasi ini nilai variasi ukuran utama yang memenuhi berjumlah 14 dan yang tidak memenuhi berjumlah 2387. Dari hasil ukuran utama yang didapatkan fungsi objektif terkecil adalah train ke 38 dengan nilai $\$ 8.647 .651,71$ dan ukuran utama $\mathrm{Lpp}=56,782 \mathrm{~m}, \mathrm{~B}=13 \mathrm{~m}, \mathrm{H}=4,168 \mathrm{~m}$, dan $\mathrm{T}=2,661$ $\mathrm{m}$.

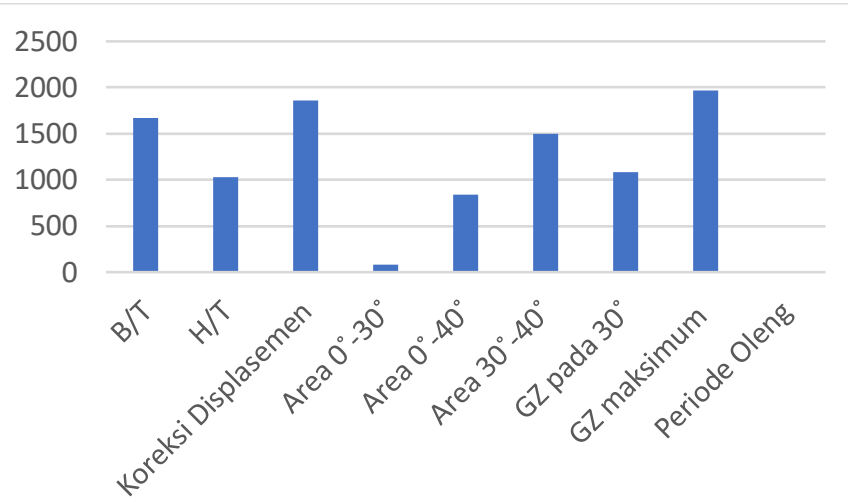

Gambar 8. Grafik jumlah nilai yang tidak memenuhi batasan pada kombinasi 7 variabel.

\section{Kombinasi 8 Variabel}

Dilakukan menggunakan nilai train 8 didapatkan hasil variasi ukuran utama $8^{4}$ sejumlah 4096. Adapun nilai yang tidak memenuhi batasan antara lain $\mathrm{B} / \mathrm{T}=2752, \mathrm{H} / \mathrm{T}=1792$, koreksi displasemen $=3147$, area $0^{\circ}-30^{\circ}=134$, area $0^{\circ}-40^{\circ}=1383$, area $30^{\circ}-40^{\circ}=2557, \mathrm{GZ}$ pada $30^{\circ}=1841, \mathrm{GZ}$ maksimal $=3366$ dan periode oleng $=19$. Seperti pada Gambar 9 berikut ini. Pada kombinasi ini nilai variasi ukuran utama yang memenuhi berjumlah 39 dan yang tidak memenuhi berjumlah 4057. Dari hasil ukuran utama yang didapatkan fungsi objektif terkecil adalah train ke 43 dengan nilai $\$ 8.591 .749,78$ dan ukuran utama $\mathrm{Lpp}=56,564 \mathrm{~m}, \mathrm{~B}=12,95 \mathrm{~m}, \mathrm{H}=4,085 \mathrm{~m}$, dan $\mathrm{T}=$ $2,633 \mathrm{~m}$.

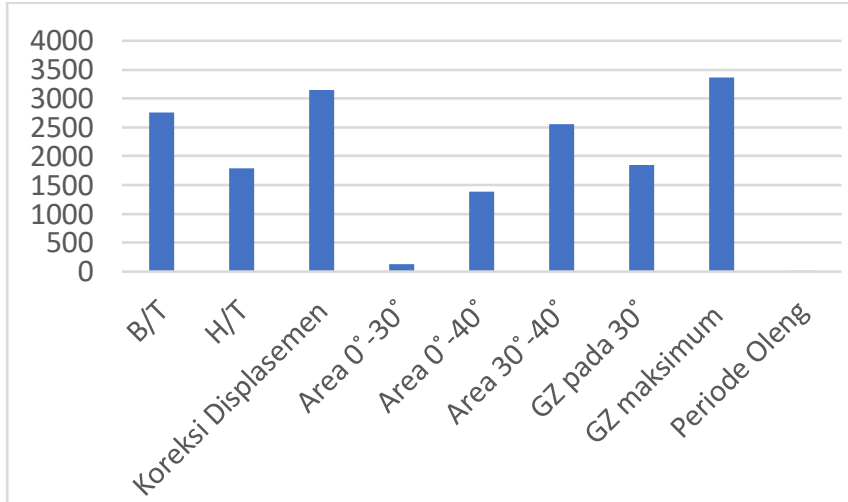

Gambar 9. Grafik jumlah nilai yang tidak memenuhi batasan pada kombinasi 8 variabel.

\section{Kombinasi 9 Variabel}

Dilakukan menggunakan nilai train 9 didapatkan hasil variasi ukuran utama $9^{4}$ sejumlah 6561 . Adapun nilai yang tidak memenuhi batasan antara lain $\mathrm{B} / \mathrm{T}=4293, \mathrm{H} / \mathrm{T}=2916$, koreksi displasemen $=4999$, area $0^{\circ}-30^{\circ}=204$, area $0^{\circ}-40^{\circ}=2169$, area $30^{\circ}-40^{\circ}=4064, \mathrm{GZ}$ pada $30^{\circ}=2857, \mathrm{GZ}$ maksimal $=5403$ dan periode oleng $=30$. Seperti pada Gambar 10 berikut ini. Pada kombinasi ini nilai variasi ukuran utama yang memenuhi berjumlah 79 dan yang tidak memenuhi berjumlah 6482. Dari hasil ukuran utama yang didapatkan fungsi objektif terkecil adalah train ke 48 dengan nilai $\$ 8.547 .947,02$ dan ukuran utama $\mathrm{Lpp}=56,394 \mathrm{~m}, \mathrm{~B}=12,911 \mathrm{~m}, \mathrm{H}=4,020 \mathrm{~m}$, dan $\mathrm{T}=$ $2,61 \mathrm{~m}$. 


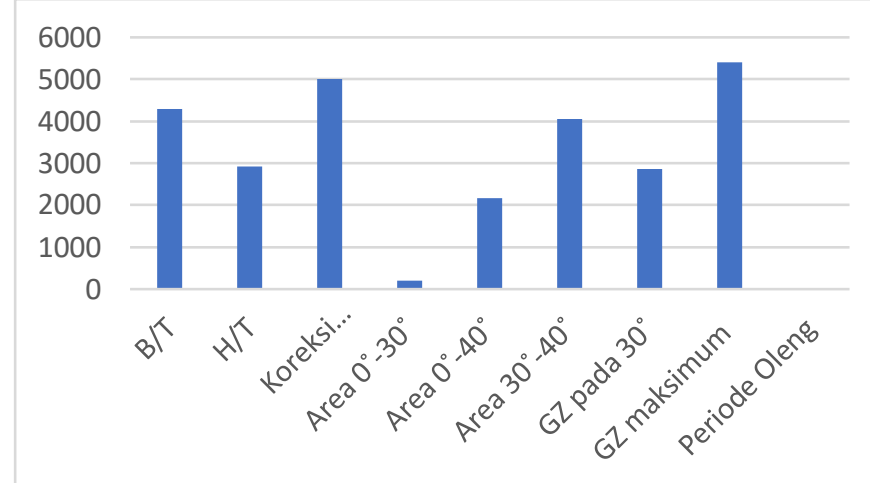

Gambar 10. Grafik jumlah nilai yang tidak memenuhi batasan pada kombinasi 9 variabel.

\section{Kombinasi 10 Variabel}

Dilakukan menggunakan nilai train 10 didapatkan hasil variasi ukuran utama $10^{4}$ sejumlah 10000 . Adapun nilai yang tidak memenuhi batasan antara lain $\mathrm{B} / \mathrm{T}=6400, \mathrm{H} / \mathrm{T}=4500$, koreksi displasemen $=7550$, area $0^{\circ}-30^{\circ}=314$, area $0^{\circ}-40^{\circ}=$ 3258 , area $30^{\circ}-40^{\circ}=6196, \mathrm{GZ}$ pada $30^{\circ}=4208$, GZ maksimal $=$ 8253 dan periode oleng $=48$. Seperti pada Gambar 10 berikut ini. Pada kombinasi ini nilai variasi ukuran utama yang memenuhi berjumlah 125 dan yang tidak memenuhi berjumlah 9875. Dari hasil ukuran utama yang didapatkan fungsi objektif terkecil adalah train ke 63 dengan nilai $\$ 8.523 .954,64$ dan ukuran utama Lpp $=56,258 \mathrm{~m}, \mathrm{~B}=12,88 \mathrm{~m}, \mathrm{H}=4,046 \mathrm{~m}$, dan $\mathrm{T}=2,592 \mathrm{~m}$.

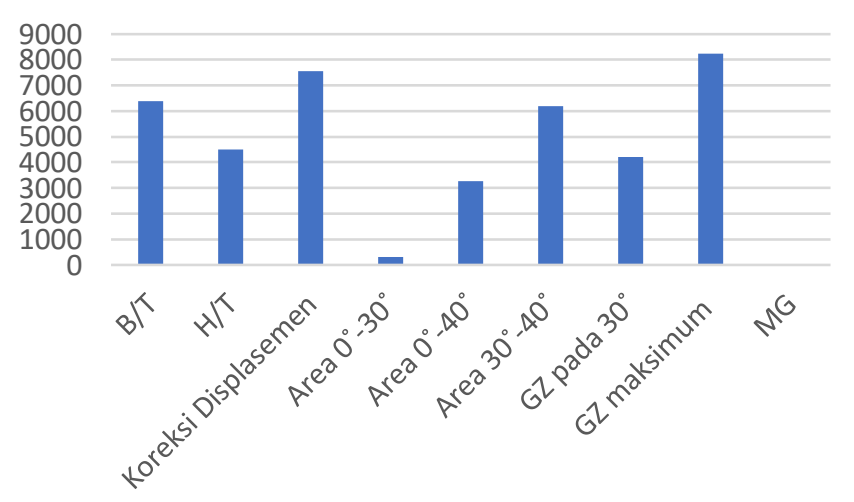

Gambar 11. Grafik jumlah nilai yang tidak memenuhi batasan pada kombinasi 10 variabel.

\section{Grafik Fungsi Objektif}

Dari setiap kombinasi sejumlah 1-10 didapatkan nilai ukuran utama yang memiliki fungsi obektif paling minimum.

Tabel 1

Hasil Fungsi Objektif Tiap Kombinasi

\begin{tabular}{clc}
\hline \hline Kombinasi & \multicolumn{1}{c}{ Biaya Pembangunan } & Selisih \\
\hline 1 & Tidak Memenuhi Batasan & \\
2 & Tidak Memenuhi Batasan & \\
3 & Tidak Memenuhi Batasan & \\
4 & $\$ 8.934 .388,72$ & \\
5 & $\$ 8.785 .324,19$ & $1.67 \%$ \\
6 & $\$ 8.722 .639,95$ & $0.71 \%$ \\
7 & $\$ 8.647 .651,71$ & $0.86 \%$ \\
8 & $\$ 8.591 .749,78$ & $0.65 \%$ \\
9 & $\$ 8.547 .947,02$ & $0.51 \%$ \\
10 & $\$ 8.523 .954,64$ & $0.28 \%$ \\
\hline \hline
\end{tabular}

Kemudian dibuat grafik dengan sumbu x sebagai kombinasi dan sumbu y sebagai fungsi objektif terkecil. Untuk lebih detailnya sebagai berikut.

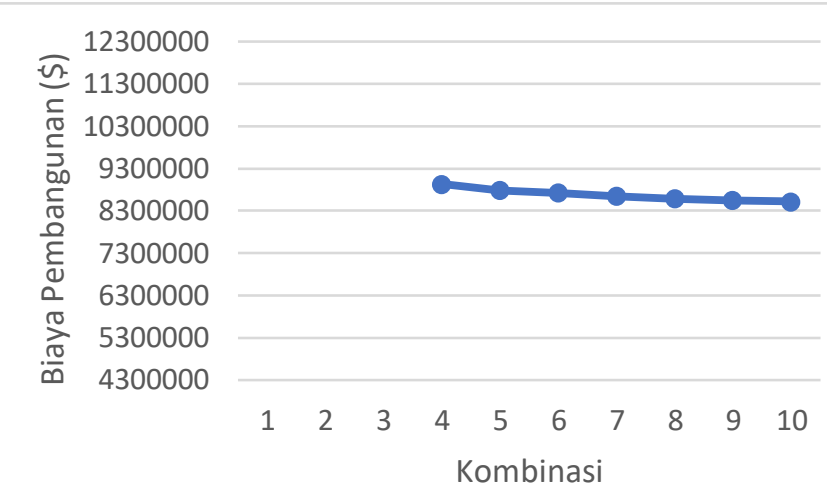

Gambar 12. Grafik fungsi objektif.

\section{Analisis Teknis}

Setelah proses optimisasi dilakukan akan mendapatkan ukuran utama yang optimum. Langkah selanjutnya adalah masuk kedalam proses perhitungan seperti perhitungan hambatan dan daya mesin, perhitungan berat kapal, freeboard, stabilitas, dan perhitungan biaya pembangunan yang sesuai ukuran utama yang optimum.

\section{Perhitungan Hambatan dan Daya Mesin}

Untuk menghitung hambatan pada saat kapal bergerak kedepan maka digunakan kecepatan kapal penuh. Metode yang digunakan untuk menghitung tahanan ini adalah metode Holtrop. Selanjutnya dari hasil perhitungan tahanan dikalikan efisiensi dan kecepatan kapal maka dapat diprediksi besar daya mesin induk [14]. Dari ukuran utama optimal hasil dari optimisasi di dapatkan nilai tahanan viscous sebesar 14.167,96 $\mathrm{N}$, tahanan gelombang sebesar 837,70 $\mathrm{N}$, dan correlation allowance sebesar 3.730,89 N. Sehingga didapatkan tahanan total sebesar $18.736,55 \mathrm{~N}$.

Tabel 2

Perhitungan Hambatan

\begin{tabular}{|c|c|c|}
\hline Item & Unit & Value \\
\hline Viscous resistance & $\mathrm{N}$ & $14.167,96$ \\
\hline Wave-making resistance & $\mathrm{N}$ & 837,70 \\
\hline Correlation allowance & $\mathrm{N}$ & $3.730,89$ \\
\hline Total Resistance & $\mathrm{N}$ & $18.736,55$ \\
\hline
\end{tabular}

Setelah diketahui hambatan total maka didapatkan perhitungan komponen propulsi kapal dengan MCR sebesar $1118,55 \mathrm{~kW}$ untuk masing masing mesin induk. Dalam pemilihan mesin induk, daya dari mesin yang terdapat pada katalog harus lebih besar dari nilai MCR yang telah direncanakan. Mesin induk dipilih menggunakan merk MAN B\&W 6L28/32A. Karena besar MCR adalah 1118,55 kW maka mesin induk dipilih dengan MCR sebesar $1470 \mathrm{~kW}$.

\section{Perhitungan Berat Kapal}

Satu hal komponen penting dalam mendesain kapal adalah perhitungan berat kapal, yang akan berpengaruh langsung pada stabilitas kapal, performance, dan biaya. Perhitungan berat kapal dilakukan berdasarkan yang diberikan David G.M Watson dalam bukunya Practical Ship Design. Perhitungan dibagi menjadi 2 bagian yaitu LWT dan DWT [10]. 
Dari optimisasi yang telah dilakukan didapatkan ukuran utama yang optimal yang memiliki berat struktural kapal sebesar 481,9257 ton dengan berat machinery sebesar 140,55 ton dan berat outfit dan ramp door sebesar 186,15 ton. Sehingga didapatkan berat total LWT sebesar 808,63 ton. Untuk lebih detailnya seperti pada dibawah ini.

Tabel 3

Berat Total LWT

\begin{tabular}{lcl}
\hline \multicolumn{1}{c}{ Item } & Berat & Satuan \\
\hline Struktur Kapal & 481,9257 & Ton \\
Machinery & 140,5536 & Ton \\
Outfit dan Ramp Door & 186,1508 & Ton \\
Berat Total LWT & 808,63 & Ton \\
\hline \hline
\end{tabular}

Dari optimisasi yang telah dilakukan didapatkan ukuran utama yang optimal yang memiliki berat total dead weight (DWT) sebesar 434,36 ton. Untuk lebih detailnya seperti pada berikut ini.

Tabel 4

Berat Total DWT

\begin{tabular}{lcl}
\hline \multicolumn{1}{c}{ Item } & Berat & Satuan \\
\hline Bahan Bakar & 10,67 & Ton \\
Minyak Pelumas & 40,00 & Ton \\
Air Tawar & 120,36 & Ton \\
Perlengkapan Penumpang & 60,18 & Ton \\
Provisions & 7,08 & Ton \\
Muatan & 178,55 & Ton \\
Berat Total DWT & 416,84 & Ton \\
\hline \hline
\end{tabular}

\section{Perhitungan Lambung Timbul}

Perhitungan lambung timbul merupakan salah satu persyaratan keselamatan kapal. Hal ini dikarenakan lambung timbul memiliki fungsi sebagai daya apung cadangan ketika kapal berlayar. Untuk menghitung perhitungan lambung timbul digunakan peraturan ILLC 1966 [15].

Didapatkan hasil koreksi freeboard minimum sebesar 350,05 $\mathrm{mm}$, Setelah dilakukan proses optimisasi dihasilkan nilai freeboard dari ukuran utama yang optimal sebesar $1454 \mathrm{~mm}$. Karena nilai tersebut lebih besar dari pada nilai freeboard koreksi maka nilai freeboard yang digunakan adalah $1454 \mathrm{~mm}$.

Tabel 5

Koreksi Freeboard

\begin{tabular}{lcc}
\multicolumn{3}{c}{ Koreksi Freeboard } \\
\hline \hline \multicolumn{1}{c}{ Item } & Panjang & Satuan \\
\hline Freeboard Awal & 450,064 & $\mathrm{~mm}$ \\
Koreksi Panjang & 450,064 & $\mathrm{~mm}$ \\
Koreksi Cb & 482,629 & $\mathrm{~mm}$ \\
Koreksi Tinggi (D) & 530,050 & $\mathrm{~mm}$ \\
Koreksi Bangunan Atas & 350,050 & $\mathrm{~mm}$ \\
Koreksi Lambung Timbul & 350,050 & $\mathrm{~mm}$ \\
\hline \hline
\end{tabular}

\section{Perhitungan Stabilitas Kapal}

Stabilitas dapat diartikan sebagai kemampuan kapal untuk kembali ke keadaan semula setelah dikenai oleh gaya luar dan merupakan persyaratan utama untuk mengukur keselamatan kapal yang akan berlayar. Kemampuan tersebut dipengaruh oleh lengan dinamis (GZ) yang membentuk momen kopel yang menyeimbangkan gaya tekan ke atas dengan gaya berat. Komponen stabilitas terdiri dari GZ, KG dan GM. Kemudian setelah harga GZ didapat, maka dilakukan pengecekan dengan Intact Stability Code.

\section{Perhitungan Biaya Pembangunan}

Biaya pembangunan kapal dapat diartikan sebagai biaya investasi yang memiliki jenis biaya seperti biaya material untuk struktur bangun kapal (structural weight cost), biaya peralatan dan perlengkapan (hull outfitting cost), biaya permesinan (machinery cost), modal cost, asuransi, perawatan dan pajak pemerintah dll [10]. Perhitungan estimasi biaya pembangunan tersebut dihitung berdasarkan biaya pada tahun 1993 dan termasuk didalamnya biaya material, tenaga kerja dan overhead.

Dari optimisasi ukuran utama yang optimum didapatkan hasil fungsi objektif biaya pembangunan kapal minimal sebesar $\$$ $8.523 .954,64$. Selanjutnya dilakukan perbandingan antara biaya pembangunan kapal existing dengan biaya pembangunan kapal hasil dari optimasi ukuran utama yang optimal. Dari ukuran utama awal didapatkan total biaya pembangunan sebesar \$ 9.532.427,67. Sehingga perbandingan biaya pembangunan kapal existing dan biaya pembangunan hasil ukuran utama hasil optimasi adalah $10.58 \%$ dengan selisih biaya pembangunan sebesar \$ 1.008.473,03.

\section{Desain Rencana Garis}

Setelah didapatkan ukuran yang optimum dibuat desain rencana garis. Untuk lebih detailnya seperti pada Gambar 13 berikut ini.

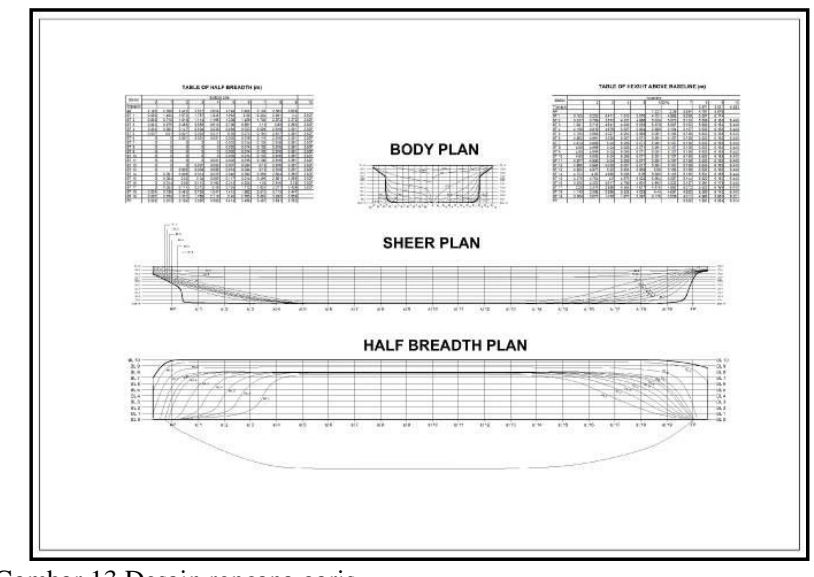

Gambar 13 Desain rencana garis.

\section{E. Desain Rencana Umum}

Setelah dibuat rencana garis dari hasil ukuran utama yang optimum, selanjutnya dibuat desain rencana umum. Adapun hal-hal yang harus diperhatikan dalam pembuatan general arrangement dari kapal ini adalah penataan geladak kendaraan, geladak akomodasi penumpang serta geladak awak kapal dan anjungan yang baik agar memberikan ruang yang optimal untuk crew, muatan, penumpang, dan demi kenyamanan saat beroperasi. Desain rencana umum kapal dapat dilihat pada Gambar 14.

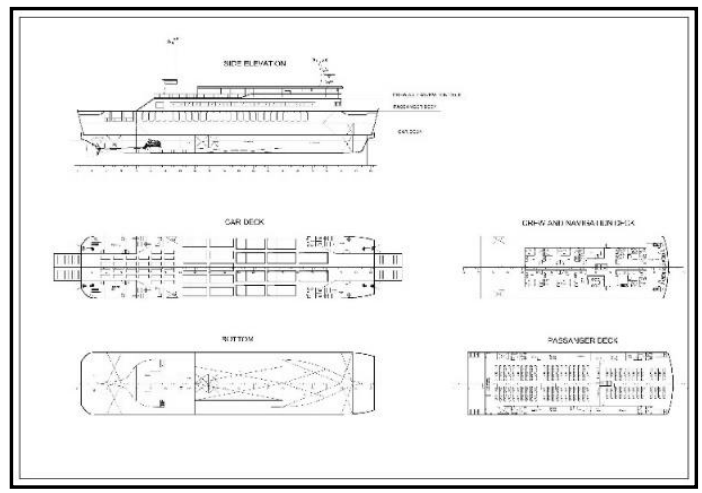

Gambar 14. Desain rencana umum 


\section{F. Desain Rencana Keselamatan}

Dalam pembuatan desain rencana keselamatan kapal mengacu pada peraturan International Maritime Organization (1988) dalam SOLAS Chapter III, berikut ini adalah beberapa peralatan keselamatan jiwa yang terdapat di kapal antara lain lifeboat, lifebuoys, lifejackets, line throwing appliances, muster station, escape route, dan peralatan peralatan kebakaran antara lain control panel and fire detection system, fire control safety plan, fire alarm bell, fire hydrant and hose, portable CO2 fire extinguisher, portable dry powder fire extinguisher, portable foam fire extinguisher, serta sprinkle and heat detector. Pada Gambar 15 adalah desain rencana keselamatan yang dibuat hasil ukuran utama yang optimal.

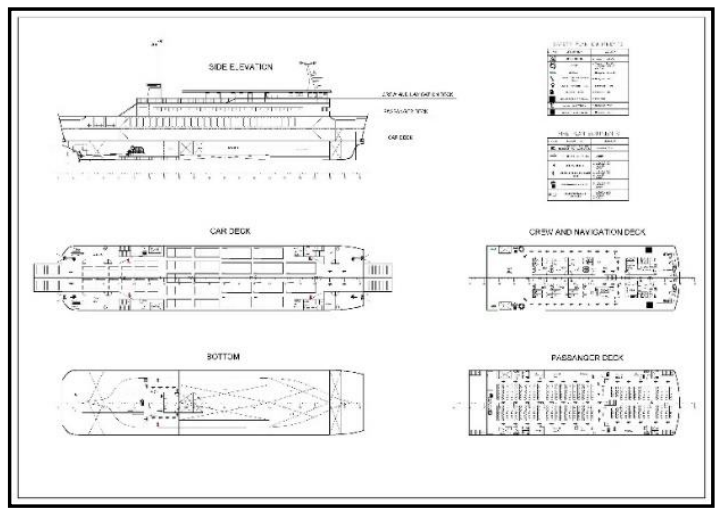

Gambar 15. Desain rencana keselamatan.

\section{G. Desain 3D}

Pembuatan awal model 3D menggunakan maxsurf modeler, setelah itu diexport ke software Rhinoceros, untuk mendetailkan model 3D. Desain 3D dapat dilihat pada Gambar 16.

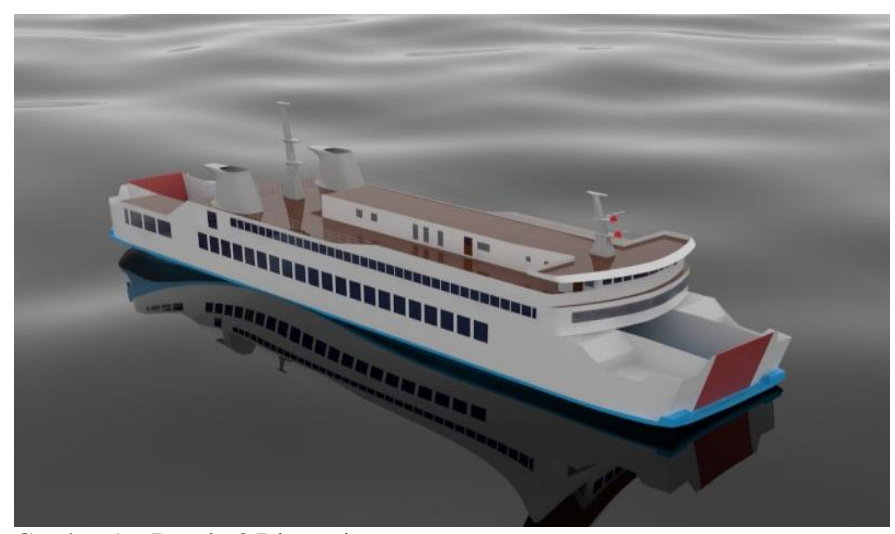

Gambar 16. Desain 3 Dimensi.

\section{KESIMPULAN}

1. Progam yang telah dibuat dan dapat berfungsi untuk melakukan optimisasi ukuran utama kapal ferry (Ro-Ro).
Optimisasi tersebut menggunakan metode artificial neural network (ANN) dengan bantuan microsoft excel yang tersambung langsung dengan maxsurf.

2. Logaritma yang telah dibuat berfungsi untuk mengontrol maxsurf menggunakan bahasa pemrogaman visual basic for application yang terdapat di microsoft excel.

3. Dari optimisasi yang telah dilakukan menggunakan kombinasi 1 - 10 sehingga didapatkan jumlah nilai train 1 - 10000. Didapatkan ukuran utama kapal yang optimal sebagai berikut :

$\begin{array}{lll}\text { Panjang }\left(\mathrm{L}_{\mathrm{PP}}\right) & : 56,258 \text { meter } \\ \text { Breadth }(\mathrm{B}) & : 12,88 \text { meter } \\ \text { Height }(\mathrm{H}) & : 4,046 \text { meter } \\ \text { Draft }(\mathrm{T}) & : 2,592 \text { meter }\end{array}$

Biaya Pembangunan : \$ 8.523.954,64

4. Dari ukuran optimum tersebut dibuat desain rencana garis (lines plan). Dan selanjutnya dibuat desain rencana umum (general arrangement) kapal ferry (Ro-Ro), desain rencana keselamatan (safety plan) dan desain 3D.

\section{DAFTAR PUSTAKA}

[1] S. S. Rao, Engineering optimization: theory and practice. John Wiley \& Sons, 2009.

[2] PT. R95 Naval Architect, "Kajian Penerapan Damage Stability Sesuai Rekomendasi Solas Terhadap Kapal-Kapal Penyeberangan Penumpang Roro Lintas Bajo'e - Kolaka," Kementrian Perhubungan, Jakarta Pusat, 2015.

[3] T. Lamb, Ship Design and Construction, vol. 1 and 2. New Jersey: Society of Naval Architects and Marine Engineers., 2003

[4] Hamzah, B. Lukman, M. R. Alwi, A. Ardianti, and F. Lukita Minra, "Optimasi Konstruksi Geladak Punumpang Kapal Ferry RO-RO 200 GT," Jurusan Perkapalan Fakultas Teknik Universitas Hasanuddin, vol. 7, 2013.

[5] L. Muzdalifah, D. Chrismianto, and E. S. Hadi, "Analisa Keselamatan Kapal Ferry Ro-Ro Ditinjau Dari Damage Stability Probabilistik," S1 Teknik Perkapalan, Fakultas Teknik, Universitas Diponegoro, Indonesia, vol. 4, 2016.

[6] H. M. Gaspar, A. Ross, D. Rhodes, and S. O. Erikstad, "Handling Complexity Aspects in Conceptual Ship Design," Int'l Maritime Design Conference Glasgow, UK, June 2012, 2012.

[7] A. Papanikolaou, Ship design: methodologies of preliminary design. Springer, 2014.

[8] A. Papanikolaou, Risk-based ship design: Methods, tools and applications. Springer Science \& Business Media, 2009.

[9] Hasanudin, "Desain Kapal LCU TNI-AL Menggunakan Metode Optimisasi," Kapal, vol. 12, no. 1, pp. 31-41, 2015.

[10] D. G. Watson, Practical ship design, vol. 1. Elsevier, 1998.

[11] V. V. Zumar and H. Hasanudin, "Desain Multipurpose Landing Craft Tank (LCT) Menggunakan Metode Optimisasi Global dan Lokal," Jurnal Teknik ITS, vol. 7, no. 1, pp. 99-104, 2018.

[12] G. Gan, An Introduction to Excel VBA Programming: with Applications in Finance and Insurance. CRC Press, 2017.

[13] M. Maxsurf, Automation Manual. Bentley System, 2013.

[14] J. Holtrop and G. G. Mennen, "An approximate power prediction method," 1982.

[15] IMO, "International Convention On Load Lines, 1966 Protocol of 1988," 1988. 